Available online at GSC Online Press Directory

GSC Biological and Pharmaceutical Sciences

e-ISSN: 2581-3250, CODEN (USA): GBPSC2

Journal homepage: https://www.gsconlinepress.com/journals/gscbps

(RESEARCH ARTICLE)

\title{
Phenotypic and molecular characterization of polyploidy Vicia faba induced by colchicine
}

\author{
Elhaddad Nagat ${ }^{1, *}$, Blash Kamla ${ }^{2}$ and Khatab Hoda ${ }^{1}$ \\ Department of Botany, Faculty of Science, University of Omar Al-Mukhtar.
}

Publication history: Received on 14 June 2020; revised on 22 June 2020; accepted on 26 June 2020

Article DOI: https://doi.org/10.30574/gscbps.2020.11.3.0184

\begin{abstract}
To induce polyploidy in diploid control plant of Vicia faba, seeds were socked in various concentrations of colchicine $(0.1,0.2,0.3$ and $0.4 \%)$ for 9 and $18 \mathrm{~h}$. Putative ploidy plants were confirmed by screening morphological characters, measuring DNA content via spectrophotometer and analyzing stomatal behavior. Polyploidy plants showed slower growth rate along with increased potency and thickened large leaves. Three types of polyploidy were achieved; triploid, tetraploid and mixoploid. In induced polyploid plants, the length and width of stomata were increased, while the index of stomata was declined, in comparison to the initial diploid plants. Treatment with 0.3 and $0.4 \%$ colchicine for 9 and $18 \mathrm{~h}$ were efficiently induced polyploidy. The highest stomatal size $(22.53 \mu \mathrm{m})$ and widest stomatal aperture $(9.72 \mu \mathrm{m})$ and the lowest stomatal index (34.24) where obtained when $0.4 \%$ of colchicine where applied at $18 \mathrm{hr}$ tested time with high significant differences at $p<0.05$ in comparison to dipliod plants. We recommend this method for induction of polyploids in other different crops and possibly will selected these tetraploid plants for further breeding purposes.
\end{abstract}

Keywords: Colchicine; Spectrophotometer; Vicia faba; Stomatal behavior; Polyploidy; Morphological traits.

\section{Introduction}

Artificial polyploidy is considered as a valuable tool for improving the genetics of many plants and consequently changes the morphological, anatomical, and physiological characteristics of plants [1, 2, 3]. Polyploid species had improved potency and performance compared to their diploid, polyploids were used as one of the main targets of plant breeding programs [4]. The plants caused by polyploidy have increased a range of morphological and yield characteristics, such as higher height, larger tuber, rhizome or root size [5]. Increased biomass, increased photosynthetic capacity, larger flowers, fruits and seeds, compared with their diploid relatives [6]. It also increases the production of essential medicinal compounds and makes the plants more stress-resistant $[7,8,9]$. Polyploidy induction may occur through sexual polyploidization, or asexual chromosome duplication. Inhibiting mitotic spindle fibers from forming into induced polyploidy by applying some chemicals induces polyploidy in plants. Colchicine is the most well-known of these chemicals, which often causes chromosome duplication [10]. It has been used for many years in plant breeding approach $[11,6]$. Under in vitro conditions, colchicine is used as an anti-mitotic agent for chromosome duplication. The effect of colchicine on in vitro chromosome duplication is different in terms of its concentration, method and duration of treatment, and also in terms of genetic factors of treated plants $[8,11]$. The polyploidy generation methods are divided into direct and indirect methods. Chromosome counting in mitotic cells and the measurement of DNA content were used as direct methods, while cytological features such as stomata cell size, stomata density, pollen grain diameter and number of chloroplasts in guard cells were used as indirect methods of polyploid determination $[11,12,13]$. The Fabaceae family Faba bean (Vicia faba) is an agricultural crop, as well as an important model plant for molecular genetics. The number of Faba bean chromosomes is $2 \mathrm{n}=12$, with one metacentric pair and five sub-telocentric chromosome pairs. DNA content is a strong ploid level predictor as it increases with the chromosome replication that occurs in polyploidy. The optical density of extracted DNA, measured by spectrophotometry and/or by electrophoresis

\footnotetext{
${ }^{*}$ Corresponding author: Elhaddad Nagat
} 
of the agarose gel, will therefore also rise. These methods also speed up the process of ploidy determination of in vitro regenerated plants and provide a rough estimate of ploidy changes after ploidy induction [14]. Also stomatal behavior as an indirect method was used for recognition of polyploid in various plants. Morphologically, the effects of polyploidy were assessed using morphological features of the leaves and stomata were known to be affected by ploidy level $[15,16]$.

The objective of the present work was to generate the polyploid of diploid Vicia faba plants using colchicine and then determine the ploidy plants by investigating different morphological diameters, measuring DNA content, and studying stomatal behavior.

\section{Material and methods}

\section{$2.1 \quad$ Seed treatment}

Disinfected seeds (180) of faba bean were presoaked in distilled water for $20 \mathrm{~h}$ at $25 \pm 2{ }^{\circ} \mathrm{C}$ and then germinated in sterilized cotton for 4-7 days. Thereafter, seeds were transferred to $(0.1,0.2,0.3$ and $0.4 \%)$ of colchicine (talented in $100 \mathrm{ml}$ distilled water) for two periods of 9 and 18 hours. After treatment, seeds were washed under running tap water for one hour and then sown in the earthen pots in the Botanical garden. For control, 20 seeds each were soaked in distilled water for 9 and $18 \mathrm{~h}$ and then sown in the earthen pots. Finally, Vicia faba seeds were sown on (1 soil: 1 botams:1/4 sand) in $10 \mathrm{~cm}$ pots and grown under a $16 \mathrm{~h}$ light/8 h dark regime with relative humidity of $65-70 \%$. All measurements were conducted in 3 - 4 weeks old.

\subsection{Selection of ploidy plants and analysis}

On the basis of morphology, putative polyploid plants were selected as they appeared to be longer in length, thicker and darker leaves and showed delayed growth in comparison of diploid control plants.

\section{$2.3 \quad$ Isolation of genomic DNA}

Leaf material from treated and untreated plants was used for DNA extraction. $700 \mu$ l extraction buffer (200 mm Tris$\mathrm{HCl}, \mathrm{pH}$ 8.0, $250 \mathrm{mM} \mathrm{NaCl}, 25 \mathrm{mM}$ EDTA, pH 8.0 and $0.5 \%$ SDS) was added to the plant material after macerating in a $1.5 \mathrm{ml}$ Eppendorf tube. The tube was vortexed briefly and centrifuged for $1 \mathrm{~min}$ at 18,000 rpm. The supernatant (600 $\mu \mathrm{l})$ was then transferred to a fresh Eppendorf tube. $600 \mu \mathrm{l}$ absolute isopropanol was added and the sample centrifuged at $18,000 \mathrm{rpm}$ for $5 \mathrm{~min}$. Without disturbing the DNA pellet in the bottom of the tube, the supernatant was removed using a Pasteur pipette. The DNA pellet was dried to remove any remaining liquid and finally, DNA re-suspended in 100 $\mu \mathrm{l}$ of sterile deionized water and stored at $-20^{\circ} \mathrm{C}$. Genomic DNA was extracted from four randomly selected leaves from control and each treatment and spectrophotometry analyzed the DNA material by measuring the optical density at 260 $\mathrm{nm}$ [17].

\subsection{Analysis of stomatal behavior}

\subsubsection{Analysis of stomatal numbers}

Impressions were made of the abaxial (lower surfaces) surface of leaves for epidermal cell and stomatal counting. Three mature fully expanded rosette leaves were excised from three different plants of each treatment (9 leaves in total). Clear nail polish was used to make the impressions of the widest area of each leaf and left for a few minutes to set and allowed to completely dry. Nail polish patches were gently peeled. The peeled impressions were then placed on clean slides and the cover slip placed over [18]. Three different areas for each impression patch were examined under the light microscope. The number of stomata and epidermal cells were also obtained to calculate stomatal index using the equation:

$$
\text { Stomatal index }=\frac{\text { stomatal number }}{\text { stomatal number }+ \text { epidermal number }} X 100
$$

\subsubsection{Stomatal size and width analysis}

Direct measurements of stomatal apertures were taken using nail polish epidermal strips. The abaxial epidermis was peeled from fully expanded leaves and analyzed using a method described by [18]. Strips of abaxial epidermis were prepared from three to five leaves of each treatment. Stomatal apertures were measured when appropriate. Pore lengths and widths were observed by light microscopy (Olympus BX41) using a fitted camera (Olympus digital camera unit). To measure the stomatal size, the measurements were started from the top beginning to the bottom end of the 
whole stoma. Whereas, to measure the stomatal width, the measurements were started from the beginning of the outer lip of first guard cell to the outer edge of the second guard cell outer lip. At each time point, 40 cells were measured for each treatment. Therefore, 120 stomata were measured for control and each treatment. To process the captured images, Image 1.48 software was used in order to measure the stomatal length and width.

\subsection{Statistical analysis}

Un-paired t-tests were used to compare the stomatal length, width and index of both controls and polyploidy plants. For each time point, 3 to 5 replicates were used for treated and un-treated plants and 120 stomata were measured. Data were performed using Minitab computing software, results with $p<0.05$ were considered to be statistically significant.

\section{Results}

\subsection{Spectrophotometric analysis}

The spectrophotometric analysis indicated four different kinds of ploidy level; diploid, triploid, tetraploid and mixoploid. The means of DNA content of untreated plants was 22.75 hg whereas 35,44 and 79 hg were obtained in a putative triploid, tetraploid and mixoploid plants respectively. Induced polyploids differed among the colchicine treatments of both concentrations and periods.

\subsection{Leaf and stomata morphological characteristics}

Polyploidy plants were evaluated morphologically, using traits known to be affected by ploidy level such as plant height, leaves number and leaf thickness [15,16]. Polyploidy plants were higher and had thicker stems and darker, bigger and thicker green leaves than diploid. Polyploidy were taller than the diploid plants of similar age (Figure 1.A and B). Six weeks old polyploidy plants had larger and thicker leaves than the diploids, (Figure 1.C and D).
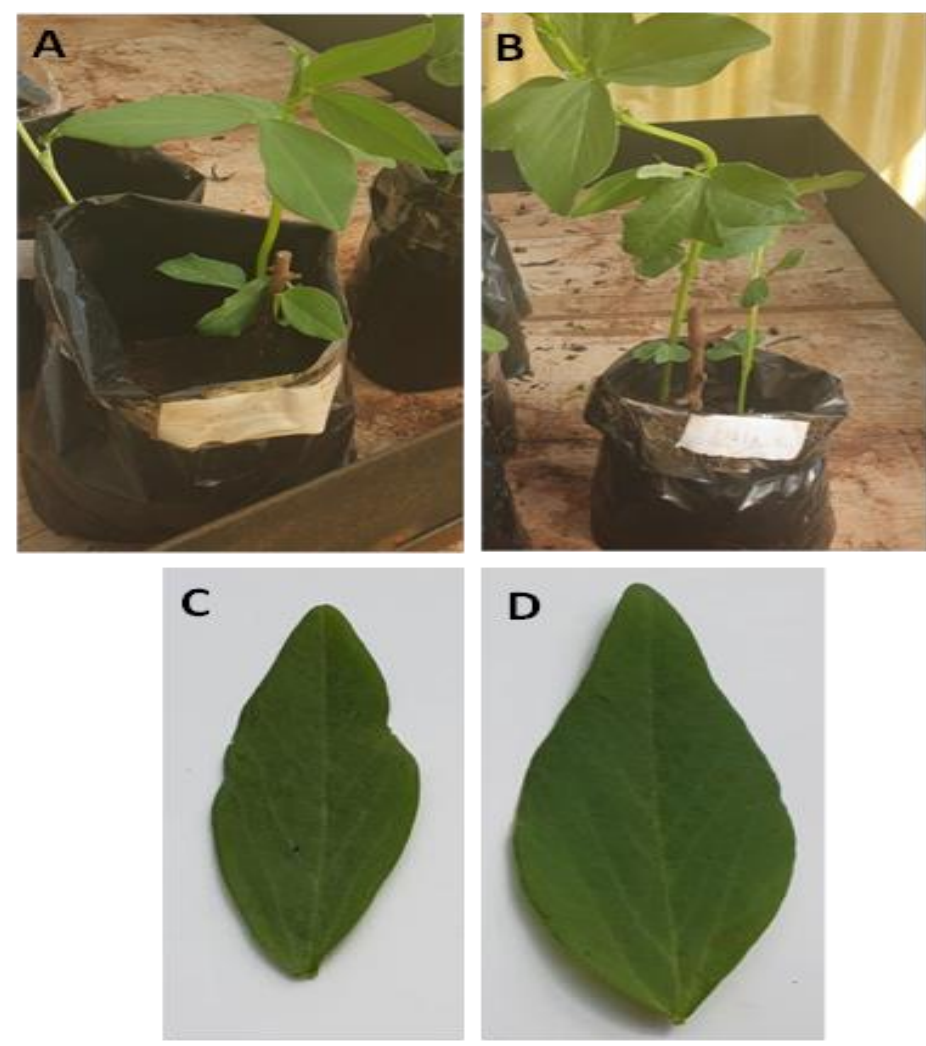

Figure 1 Field variation between diploid and tetraploid Vicia faba. Control plant height (A), tetraploid plant height (B); diploid (C) and tetraploid (D) leaf size. 
In regard to stomatal characteristics, polyploidy plants had larger stomatal size and fewer stomatal number than control plants (Figure 2). In polyploidy leaves; stomatal length and width (Figure 3 and 4) were significantly larger than control plants whereas stomatal index (Figure 5) were significantly less in polyploidy plants than in diploids. Our outcomes indicating that two concentrations of colchicine $(0.3$ and $0.4 \%)$ were successfully able to induce tri and tetraploidy in both time points ( 9 and $18 \mathrm{hr}$ ) in Vicia faba. There was a significant difference between control and putative triploids that treated with $0.3 \%$ of colchicine in all off stomatal size, aperture and index. $17.21 \mu \mathrm{m}$ of stomatal size, $7.5 \mu \mathrm{m}$ of stomatal aperture and 42.34 of index were achieved for diploid control plants whereas putative triploids had higher stomatal length $21.03 \mu \mathrm{m}$, width $8.99 \mu \mathrm{m}$ and lower 37.08 stomatal index than diploids. Furthermore, the highest stomatal size $(22.53 \mu \mathrm{m})$ and the broadest stomatal aperture $(9.72 \mu \mathrm{m})$ and the lowest stomatal index (34.24) where obtained when $0.4 \%$ of colchicine where applied at $18 \mathrm{~h}$ tested time with high significant differences at $p<0.05$. Although, mixoploidy plants had the highest amount of DNA in comparison to control plants, no significant differences in stomatal size (17.07 and $18.6 \mu \mathrm{m})$ and stomatal aperture (6.99 and $7.77 \mu \mathrm{m}$ ) and also stomatal index (43.08 and 43.82) in comparison with control plant at both collection times after treatment with 0.1 of colchicine. Significantly, lower stomatal index was observed in polyploidy than diploid plants (Figure 5). The average of stomatal index in control diploids was 42.34 in 9 hours' time point, whereas polyploidy plants had 41.4 and 38.68 when treated respectively with 0.3 and $0.4 \%$ colchicine. Unsurprisingly, after 18 hours of incubation time, the stomatal index reduced to 37.08 and 34.24 with same treatments.
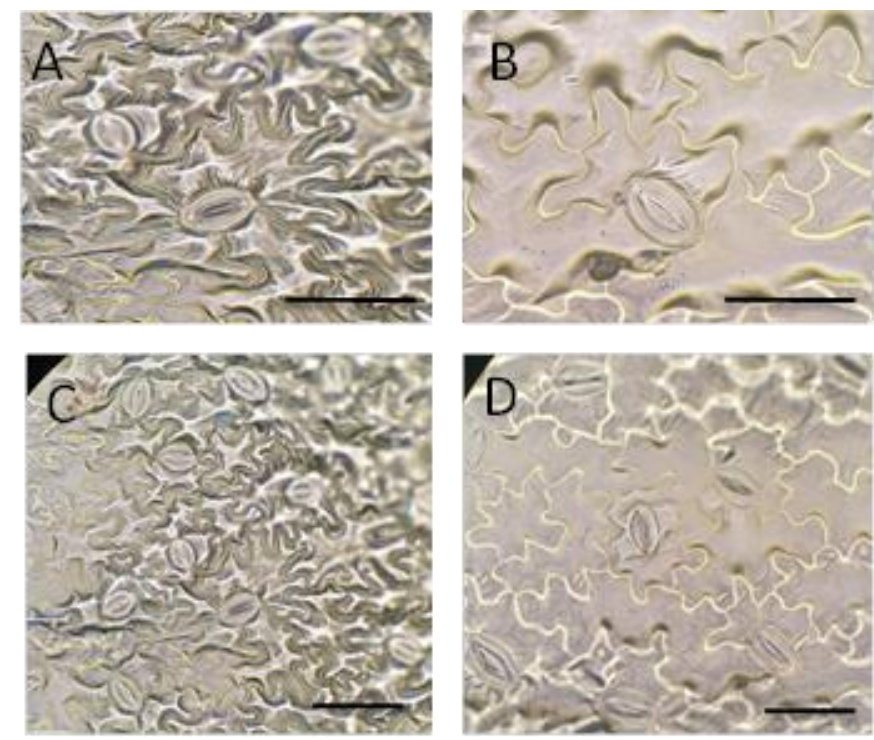

Figure 2 Stomata characteristics of Vicia faba. A. Stomata size of diploid control plants (bars $10 \mu \mathrm{m}$ ). B Stomata size of polyploidy plants (bars $10 \mu \mathrm{m}$ ). C. Stomata density of control plants (bars $100 \mu \mathrm{m}$ ). D. Stomata density of polyploidy plants (bars $100 \mu \mathrm{m})$.

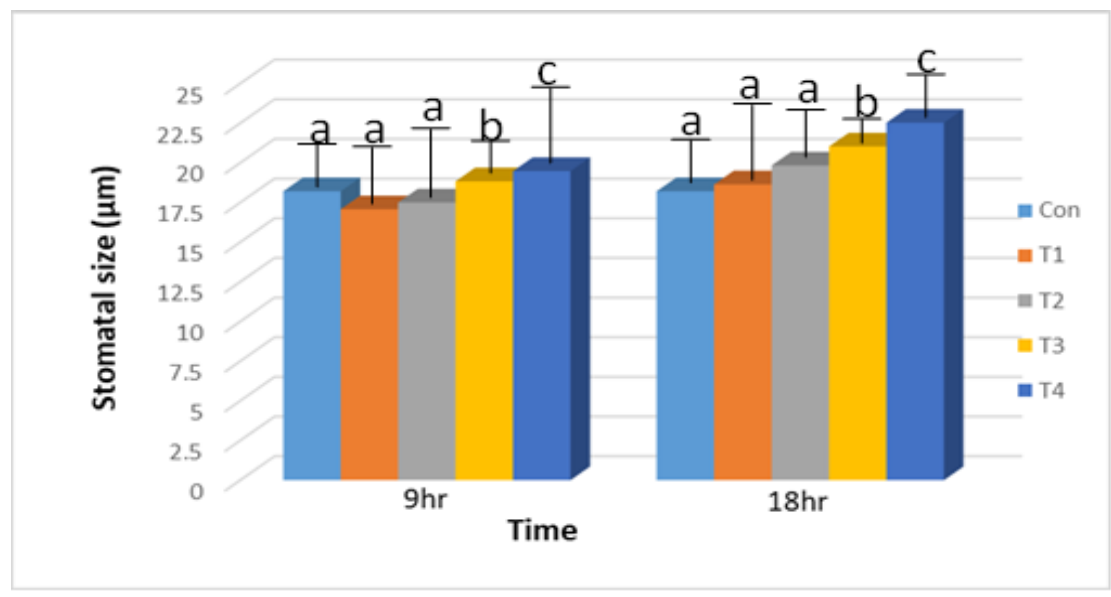

Figure 3 Stomatal size of control and treated plant with different concentration of colchicine. Stomatal size was measured from the abaxial peels of detached fully expanded leaves following treatment with colchicine. Error bars represent the standard error. Significant differences from control indicated with different letters $(p<0.05)$. 


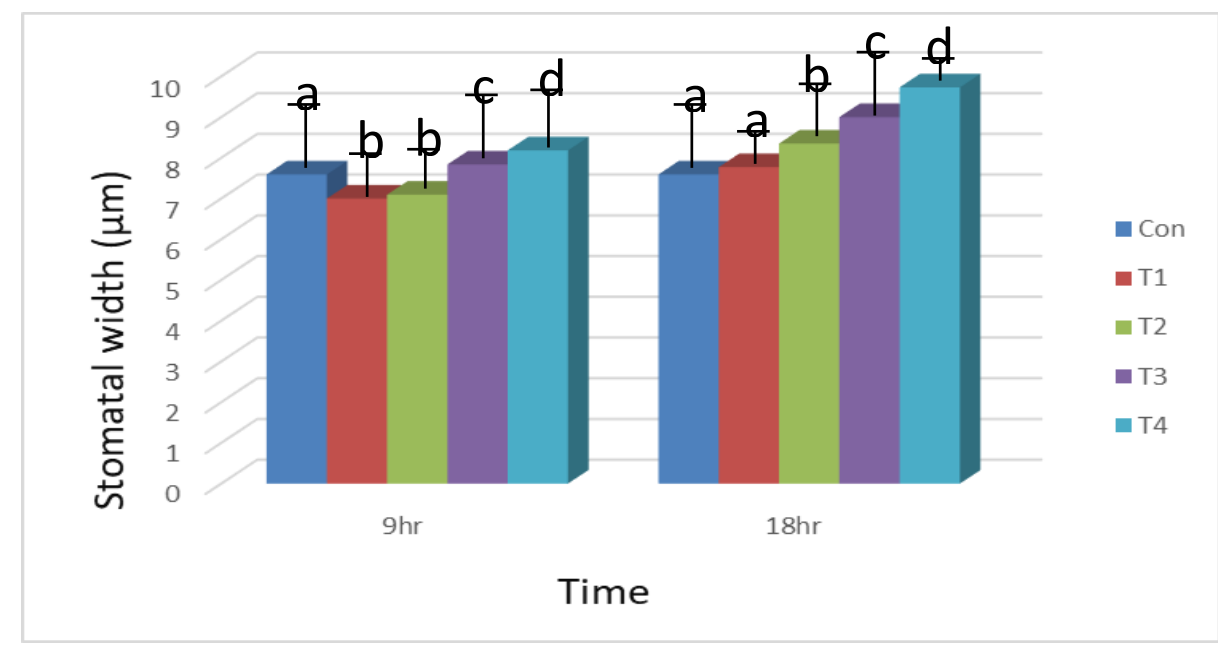

Figure 4 Stomatal width of control and treated plant with different concentration of colchicine. Stomatal apertures were measured from the abaxial peels of detached fully expanded leaves following treatment with colchicine. Error bars represent the standard error. Significant differences from control indicated with different letters $(\mathrm{p}<0.05)$.

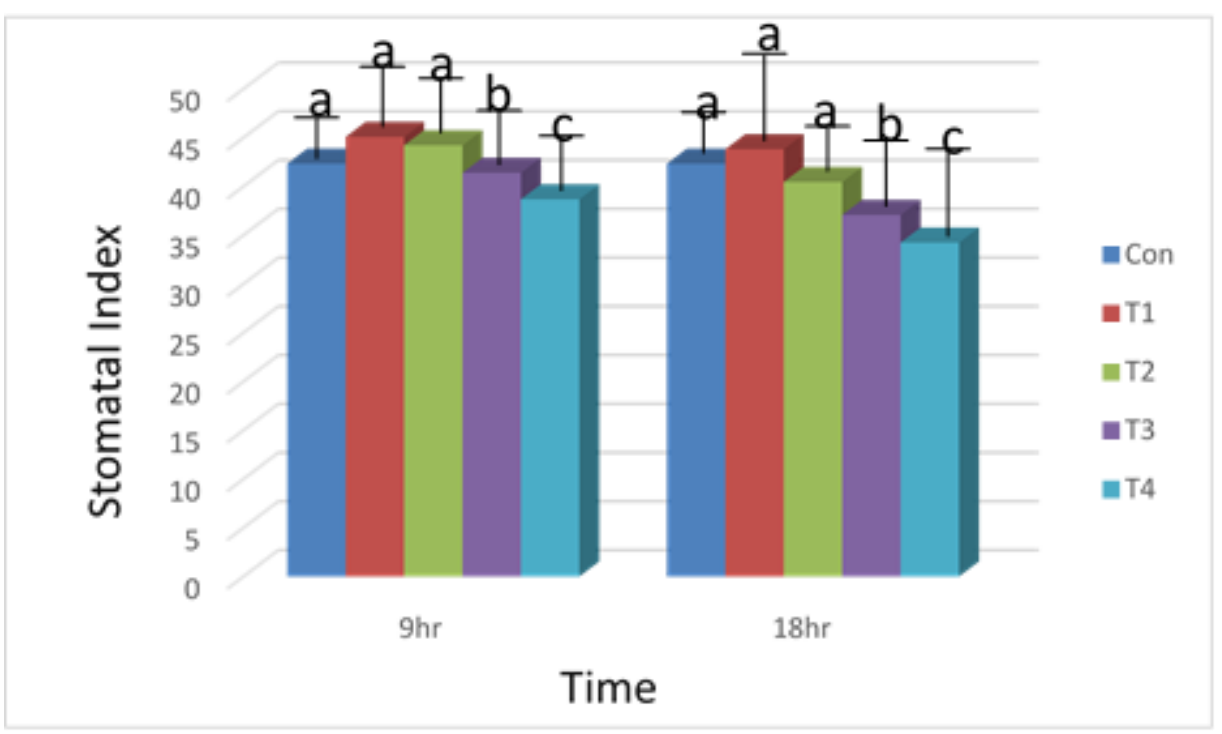

Figure 5 Stomatal index of control and plant treated with different concentration of colchicine. Stomatal index was calculated from the abaxial surface of fully expanded leaves. Error bars represent the standard error. Significant differences from control indicated with different letters $(p<0.05)$.

\section{Discussion}

One of the most features that can be used as a strong indicator of the ploidy level in plants is measuring DNA content. Optical density of total DNA content of Vicia faba plants treated with $0.3 \%$ colchicine for $18 \mathrm{~h}$ had nearly one and a half of diploid DNA content which confirms triploids. Total DNA content of $0.4 \%$ treated plants for $18 \mathrm{~h}$ was almost twice that of control groups representing tetraploids. Surprisingly, plants treated with $0.1 \%$ of colchicine had three times that of control groups might representing mixoploids as had no significant differences in comparison with diploid control plants in analysing morphological features and stomatal characteristics. As a result of chromosome replication that occurs in polyploidization, the total DNA content of plants increases. Amount of DNA can be used as an indicator for ploidy determination, so we used a spectrophotometer to calculate the optical density of extracted DNA in the treated plants and compare it with the control group. This method is quick and simple and reduces the time needed to assess ploidy of regenerated plants in vitro. Raza et al., documented this method 's effectiveness in the determination of watermelon ploidy levels [14]. Our findings also agree with related studies performed by [19,20]. Based on these results, spectrophotometer had an important role in identifying mixoploids in the present work. The chromosome elimination is one theory which could explain the occurrence of mixoploidy in the present work. [21] and [22] working in triploid 
elephant grass and millet with chromosomal duplication induction, found mixoploidy in most of the plants studied. Mixoploids may arise because of colchicine as an antimitotic agent may not always reach all of the actively dividing parts on a plant [23]. Several authors [24,25,26] have reported different effects of antimitotic agents when different tissues are targeted or different treatment periods are used. The efficiency of colchicine was documented for variant induction in several crops, medicinal and flowering plants $[27,28,29]$. The survival factor after colchicine treatment depends on the concentration and duration of the treatment. A higher concentration and longer duration of colchicine decreased the survival rate or increased the shoot tip mortality rate which supports earlier observation [30]. The lower concentration with longer period of colchicine applications results in greater frequency of induction of polyploidy [31]. In current study, lower concentrations and two different time periods were applied. We found that the morphological characteristics of treated plants such as number and thickness of Faba Bean induction plants leaves were increased and display slower growth rate. The growth rate of treated plants was slower than that of the control, especially in plantlets resulting from $18 \mathrm{~h}$ of treatment with colchicine. These morphological changes have been used to identify putative polyploidy plants. Our results were in agreement with some previous studies who reported that induced tetraploid plants grow at a slower rate than the control ones $[32,33]$. The reduced growth rate after colchicine treatment was also noted by [34] who reasoned that the decreased rate of polyploids was caused by physiological disruption caused by colchicine, which causes a reduction in the rate of cell division. Another possible reason, might be the smaller amounts of growth hormones present [35,36]. The remarkable differences in the tetraploid plants in leaf morphology and ultrastructure might also be explained by their abundant levels of steviol glycosides, since leaves is the main tissue for both the synthesis and primary deposition of glycosides [37,38]. One of the most appropriate indirect way to determine polyploids induction is analyzing stomatal behavior [39]. Stomata length as a measure of stomata size can be an indicator of ploid levels and has been used for the determination of ploid levels in different plant types [3,40,41,42]. In comparison of stomata characteristics between diploid and polyploid plants, our data reflected the significant increased length and width (Figure 3) of stomata in Faba Bean polyploid plants induced by colchicine, as opposed to their diploid. Microscopic observations have also shown significant reduced of stomatal index in the polyploid achieved plants in comparison to diploid-intact plants, (Figure 4). The lower stomatal index, most likely due to the larger stomata and epidermal cells as well as reduced stomata differentiation [43]. Many ploid-induction studies have also reported dramatic increases in stomata length and width, and decreases in stomatal count in colchicine-induced polyploid plants $[9,44,45]$. It draws support from [28]'s finding that the larger leaves in colchicine treated aloe retained an improved stomata length. Similar findings have been found on coffee and cassava [46,47]. The greater stomata and decreased frequency supported the polyploidy nature plants in the present study. Stomatal variations have been shown to be reliable and efficient ploidy markers, and sometimes faster than chromosomal counting tests [48,49].

\section{Conclusion}

In this study, in vitro, effective concentrations of colchicine were introduced for polyploid generation. The measurement of the optical density of the total DNA content via spectrophotometer allows easy recognition of putative polyploids. Morphological characteristics, such as plant height, leaf thickness and size were increased in polyploid plants as compared to their diploid. In ployploid plants, stomata length and width were also increased, while the stomata index of diploid plants was greater than induced polyploid plants. Using different methods, we conclude that all methods can be successful in determining rates of ploidy.

\section{Compliance with ethical standards}

\section{Acknowledgments}

We thank Dr. Omar Alssaady (University Research Station Manager) for his kind help in facilitating the green house and providing some important equipment. Also we would to thank Dr. Mohamed A. M. Adam for his assistance in measuring DNA content in his laboratory.

\section{Disclosure of conflict of interest}

The trial is completely devoid of conflict of interest.

\section{References}

[1] Ghani MA, Sun Q, Li J, Cao L, Rao L and Zou X. (2014). Phenotypic and genetic variation occurred during wide hybridisation and allopolyploidisation between Brassica rapa and Brassica nigra. Chen, Sci. Hortic, 176, 22-31. 
[2] Hannweg K, Sippel A and Bertling IS. (2013) A simple and effective method for the micropropagation and in vitro induction of polyploidy and the effect on floral characteristics of the South African iris, Crocosmia aurea. Afr. J. Bot. 88, 367-372.

[3] Huang H, Gao S, D. Wang P, Huang J and Li J. (2014). Autotetraploidy Induced in Nianmaohuangqin (Radix Scutellariae Viscidulae) With Colchicine in Vitro. Tradit. Chin.Med, 34,199-205.

[4] Sattler MC, Carvalho CR and Clarindo WR. (2016). The polyploidy and its key role in plant breeding. Planta 243(2), 281-296.

[5] Hannweg K, Visser G, de Jager K and Bertling I. (2016). In vitro-induced polyploidy and its effect on horticultural characteristics, essential oil composition and bioactivity of Tetradeniariparia. S Afr J Bot, 106, 186-191.

[6] Urwin NA. (2014). Generation and characterisation of colchicine-induced polyploidy Lavandulax intermedia. Euphytica, 197(3), 331-339.

[7] Lavania U. (2005). Genomic and ploidy manipulation for enhanced production of phyto-pharmaceuticals. Plant Genet. Resour, 3 170-177.

[8] Chen WH, Tang CY, Lin TY, Weng YC and Kao YL. (2011). Changes in the Endopolyploidy Pattern of Different Tissues in Diploid and Tetraploid Phalaenopsis Aphrodite Subsp. Formosana (Orchidaceae) PlantSci, 181, 31-38.

[9] Aina O, Quesenberry K and Gallo M. (2012). In vitro induction of tetraploids in Arachis paraguariensis. Plant Cell Tissue Organ Cult (PCTOC), 111(2), 231-238.

[10] Blakeslee AF and Avery AG. (1937). Methods of inducing doubling of chromosomes by treatment with colchicine. Journal of Heredity, 28, 392-411.

[11] Dhooghe E, Van Laere K, Eeckhaut T, Leus L and Van Huylenbroeck J.(2011). Mitotic chromosome doubling of plant tissues in vitro. Plant Cell Tissue Organ Cult (PCTOC), 104(3), 359-373.

[12] Jaskani M, Kwon S and Kin D. (2005). Flow cytometry of dna contents of colchicine treated watermelon as a ploidy screening method at $\mathrm{m} 1$ stage. Pak. J. Bot. 37, 685.

[13] Omidbaigia R, Mirzaeea M, Hassanib M and Moghadamc M. (2010). Induction and identification of polyploidy in basil (Ocimum basilicum L.) medicinal plant by colchicine treatment. Int. J. Plant Prod, 4, 2.

[14] Raza H, Jaskani M, Khan M and Malik T. (2003). In Vitro Induction of Polyploids in Watermelon and Estimation Based on DNA Content. Int. J. Agric. Biol, 5, 298-302.

[15] Liu G, Li Z and Bao M. (2007). Colchicine-induced chromosome doubling in Platanus acerifolia and its effect on plant morphology. Euphytica, 157(1-2), 145-154.

[16] Ye, YM, Tong, J, Shi XP, Yuan W and Li GR. (2010). Morphological and cytological studies of diploid and colchicineinduced tetraploid lines of crape myrtle (Lagerstroemia indica L.). Sci. Hortic., 124(1), 95-101.

[17] Edwards K, Johnstone C and Thompson C. (1991). A simple and rapid method for the preparation of plant genomic DNA for PCR analysis. Nucl. Acid. Res, 19, 1349.

[18] Scarpeci TE, Zanor MI and Valle EM. (2017). Estimation of stomatal aperture in Arabidopsis thaliana using silicone rubber imprints. Bio-protocol, 7(12).

[19] Colijn-Hooymans C, Hakkert J, Jansen J and Custers J. (1994). Competence for regeneration of cucumber cotyledons is restricted to specific developmental stages. Plant Cell, Tissue Organ Cult, 39, 211-217.

[20] Gao S, Zhu D, Cai Z and Xu D. (1997). Autotetraploid plants from colchicine-treated bud culture of Salvia miltiorrhiza. Plant Cell, Tissue Organ Cult, 47, 73-77.

[21] Abreu JC, Davide LC, Pereira AV and Barbosa S (2006). Mixoploidia em híbridos de capim-elefante x milheto tratados com agentes antimitóticos. Pes. Agrop. Bras, 41(11),1629-1635.

[22] Barbosa S. (2004). Micropropagação e duplicação cromossômica de híbridos triplódes de capim-elefante e milheto. Thesis, Universidade Federal de Lavras, Lavras.

[23] Carvalho JF, Carvalho CR and Otoni WC. (2005). In vitro induction of polyploidy in annatto (Bixa orellana). Plant Cell Tissue Org, 80(1),6975.

[24] Poutaraud A and Girardin P. (2005). Influence of chemical characteristics of soil on mineral and alkaloid seed contents of Colchicum autumnale. Environ. Exp. Bot, 54(2),101-108. 
[25] Campos JM, Davide LC, Salgado CC, Santos FC, Costa PN, Silva OS, Alves CCS, Viccini LF and Pereira AV (2009). In vitro induction of hexaploid plants from triploid hybrids of Pennisetum purpureum and Pennisetum glaucum. Plant Breed, 128,101-104.

[26] Wannakrairoj S and Wondyifraw T. (2013). In vitro chromosome doubling ink [Aframomum corrorima (Braun) P.C.M. Jansen] using colchicine and oryzalin. Kasetsart J. Nat. Sci, 47,684-694.

[27] Prashant Joshi and Rakesh C. Verma. (2004). High Frequency Production of Colchicine Induced Autotetraploids in Faba Bean (Vicia faba L.). Cytologia, 69(2), 141-147.

[28] Wang L, Zheng SX and Gu ZJ. (2002). In vitro culture of tetraploids of Aloe vera L. Acta Hortic Sinica, 29, $176-178$.

[29] Rose JB, Kubba J and Tobutt KR. (2001). Induction of tetraploids for breeding hardy ornamentals. Acta Hortic, 560, 109-112.

[30] Tang ZQ, Chen DL, Song ZJ, He YC and Cai DT. (2010). In vitro induction and identification of tetraploid plants of Paulownia tomentosa. Plant Cell Tiss Organ Cult, 102, 213-220.

[31] Forni-Martins ER and Cruz ND. (1985). Dados preliminaries sobre induc a o de poliploidia em Jatropha curcas (Euphorbiaceae). Congresso da Sociedade Bota `nica de Sa ^o Paulo. V. Botucatu. Resumos, 167.

[32] Shao JZ, Chen CL and Deng XX. (2003). In vitro induction of tetraploid in pomegranate (Punica granatum). Plant Cell Tiss Organ Cult, 75, 241-246.

[33] Wright JW. (1976). Introduction of forest genetics. Academic Press, New York.

[34] Stebbins GL. (1984). Polyploidy and the distributed of arctic-alpine flora: a new evidence and new approaches. Bot Helv, 94, 1-13.

[35] Avery GS and Pottorf L. (1945). Polyploidy, auxin and nitrogen in green plants. American Journal of Botany, 32, 669-671.

[36] Larsen P and Mintung S. (1950). Growth promoting and growth retarding substances in pollen from 2n and 3n apple varieties. Botanical Gazette, 3, 436-447.

[37] Yadav AK, Singh S, Dhyani D and Ahuja PS. (2011). A review on the improvement of stevia [Stevia rebaudiana (Bertoni)]. Can J Plant Sci, 91, 1-27.

[38] Yadav AK, Singh S, Yadav SC, Dhyani D, Bhardwaj G, Sharma A and Singh B. (2013). Induction and morphochemical characterization of Stevia rebaudiana colchiploids. Indian J Agric Sci, 83, 159-169.

[39] Gomes SS, Saldanha CW, Neves CS, Trevizani M, Raposo NR, Notini MM, de Oliveira Santos M, Campos JMS, Otoni WC and Viccini LF. (2014). Karyotype, genome size, and in vitro chromosome doubling of Pfaffia glomerata (Spreng.) Pedersen. Plant Cell, Tissue and Organ Cult (PCTOC), 118(1), 45-56.

[40] Hamill S, Smith M and Dodd W. (1992). In vitro induction of banana autotetraploids by colchicine treatment of micropropagated diploids. Aust. J. Bot, 40, 887-896.

[41] Miguel TP and Leonhardt KW. (2011). In vitro polyploid induction of orchids using oryzalin. Sci. Hortic, 130, 314319.

[42] Chakraborti S, Vijayan K, Roy B and Qadri S. (1998). In vitro induction of tetraploidy in mulberry (Morus alba L.) Plant Cell Rep,17, 799-803.

[43] Gantait S, Mandal N, Bhattacharyya S and Das PK. (2011). Induction and identification of tetraploids using in vitro colchicine treatment of Gerbera jamesonii Bolus cv. Sciella. Plant Cell Tissue Organ Cult (PCTOC), 106(3), 485.

[44] Majdi M, Karimzadeh G, Malboobi MA, Omidbaigi R and Mirzaghaderi G. (2010). Induction of tetraploidy to feverfew (Tanacetum parthenium Schulz-Bip.): Morphological, physiological, cytological, and phytochemical changes. HortScience, 45(1), 16-21.

[45] Xu C, Huang Z, Liao T, Li Y and Kang X. (2016). In vitro tetraploid plants regeneration from leaf explants of multiple genotypes in Populus. Plant Cell Tissue Organ Cult (PCTOC), 125(1), 1-9.

[46] Boaventura YM, Medina DM, Vieira MJ and Arruda HV. (1981). Nu 'mero de cloroplastos e nı̌vel de ploidia em espe 'cies de Coffea L. Rev Bras Bot, 4,15-21.

[47] Carvalho R, Guerra M and Carvalho PC. (1999). Occurrence of spontaneous triploids in Manihot esculenta Cruntz. Cytologia, 64, 137-140. 
[48] Evans AM. (1955). The production and identification of polyploids in red clover, white clover and Lucerne. New Phytol, 514, 149-162.

[49] De Oliveira VM, Forni-Martins ER, Magalha es PM and Alves MN. (2004). Chromosomal and morphological studies of diploid and polyploid cytotypes of Stevia rebaudiana (Bertoni) (Eupatorieae, Asteraceae). Genet Mol Biol, 27, 215-222.

\section{How to cite this article}

Elhaddad N, Blash K and Khatab H. (2020). Phenotypic and molecular characterization of polyploidy Vicia faba induced by colchicine. GSC Biological and Pharmaceutical Sciences, 11(3), 235-243. 